\title{
Verbal Emotional Disclosure of Moral Injury in Holodomor Survivors*
}

\section{Вербально-емоційне виявлення моральної травми у свідків Голодомору**}

\author{
Larysa Zasiekina \\ Ph.D., Clinical Psychology \\ and Psycholinguistics, Professor
}

\author{
Лариса Засккіна \\ доктор психологічних наук, \\ професор
}

E-mail: zasyekina.larisa@vnu.edu.ua https://orcid.org/0000-0001-8456-0774

ResearcherID: X-7055-2018

Scopus Author ID: 57215414977

Serhii Zasiekin

Ph.D., Linguistics and Translation

Studies, Professor
Сергій Засскін

кандидат філологічних наук, професор

E-mail: sergiozasyekin@,vnu.edu.ua https://orcid.org/0000-0001-9453-3534

ResearcherID: C-3094-2016

Scopus Author ID: 35112194200

Lesya Ukrainka Volyn

State University

13, Voli Avenue, Lutsk, Ukraine, 43025
Волинський національний університет імені Лесі Українки $\checkmark$ пр. Волі, 13, Луцьк, Україна, 43025

Original manuscript received March, 03, 2020

Revised manuscript accepted October, 07, 2020

* The paper is supported by the Holodomor Research and Education Consortium (HREC) of the Canadian Institute of Ukrainian Studies (CIUS), University of Alberta, as a part of the project «Moral Injury: A Comparative Study with Offspring of Holodomor and Holocaust Survivors».

** Дослідження виконано за підтримки дослідно-освітнього консорціуму з вивчення Голодомору Канадського інституту українських студій, університету Альберти в межах проекту «Моральна травма: крос-культурне дослідження нащадків свідків Голодомору та Голокосту» (2020). 


\begin{abstract}
Objectives. The purpose of the current research is to define and operationalize moral injury based on moral standards, moral judgements, moral reasoning, moral emotions, moral behaviour, and moral consequences; to explore verbal emotional disclosure of moral injury in Holodomor survivors' narratives.
\end{abstract}

Materials \& Methods. The study applies traumatic narratives of 42 survivors of the Holodomor of 1932-1933 in Ukraine. Main themes aligned with morality structure were captured, using software tool NVivo.12. The study uses LIWC2015 to search for psychological meaningful categories, notably anxiety, anger, sadness, and insights (deep comprehension). The research uses the cross-sectional design utilizing the independent variables of anxiety, anger, insights and dependent variable of moral emotions represented in narratives for multiple linear regression analysis and correlations (2-tailed Pearson r) between components of morality, anxiety, sadness and insights, SPSS. 26.

Results. There is a high frequency of moral judgements and a low frequency of moral emotions and moral consequences in the narratives. A significant positive correlation was found between moral standards and other components of morality, in particular moral judgements, moral reasoning, moral consequences, anxiety, sadness and insight. There was a significant positive correlation between moral emotions and anger, and insight. Anxiety, insights and anger taken together are significant predictors of moral emotions, however, only anger is a robust significant independent predictor of moral emotions.

Conclusions. Verbal emotional disclosure of traumatic experience relates to expressing righteous anger, contempt, disgust, decreased empathy, and embarrassment, which substitute other moral emotions, notably shame and guilt. The study contributes to our understanding of anxiety, anger, insights (deep comprehension) taken together as robust predictors of moral emotions. Finally, we captured that there are difficulties in verbal emotional disclosure of experience and moral consequences of the Holodomor, since Holodomor survivors predominantly focus on moral judgements and moral standards.

Key words: verbal emotional disclosure, moral injury, moral standards, moral judgements, moral reasoning, moral behaviour, moral emotions, moral consequences, Holodomor.

\title{
Introduction
}

Despite the importance of moral injury as psychological distress felt when individuals perpetrate, witness or fail to prevent actions which violate their core moral assumptions and beliefs, there remains a paucity of evidence on moral injury in Holodomor survivors. Several studies of traumatic memory have investigated that Holodomor survivors and their 
direct descendants demonstrate the survivor mode, expressing specific emotions and inner states (horror, fear, mistrust, sadness, ethnic-related shame, anger, stress and anxiety), and trauma-based coping strategies (overeating, intrinsic selfishness and indifference to others, overemphasis on food) (Bezo \& Maggi, 2015). The trauma-based coping strategies are caused by a strong fear of possible reoccurrence of hunger in future and expressed in seeking security linked to food (Chemtob, Novaco, Hamada \& Gross, 1997). In addition, a number of studies have postulated sadness and ethnic-related shame in Holodomor survivors (Braga, Mello \& Fiks, 2012). Since a number of cross-sectional studies suggest that moral emotions, notably shame, guilt, embarrassment mediate moral standards and moral behaviour, there is a need to understand Holodomor as morally injured event (Tangney, Stuewig \& Mashek, 2007). This idea is in line with recent research, pointing out that the concept of moral injury should be developed in the historical context, specific cultural and normal values, and applying the concept of moral injury beyond military field (Coady, Carney, Frankfurt \& Litz, 2020).

The concept of moral injury in the current study is viewed from the wider perspective of morality in general. Morality is represented by three domains, particularly cognitive (moral standards), emotional (moral emotions), and behavioral (moral intentions, moral decisions, and moral behavioral acts) (Kroll \& Egan, 2004). Moral standards are defined as interiorized knowledge of moral norms and values accepted and wellrecognized in society. Moral emotions could explain the adherence to some moral behaviour, represented by specific moral decisions according to moral standards. Shen (2018) argues that shame and guilt are similar moral emotions. Despite similar cognitive distortions, causing shame and guilt after traumatic event, they are embodied in behavioral acts differently. In particular, shame is more traumatic and damaging emotion than guilt and aligned with various mental disorders and maladaptive behaviour, notably eating disorders and self-injury. Moreover, recent findings indicate that shame is aligned with anger and lack of empathy, which results in decreasing interpersonal relations through avoiding or withdrawal (Litz et al., 2009). On the contrary, guilt is other-oriented emotion, which could enhance social contacts, however depreciate one's self.

Evidence consistently suggests that moral emotions play a crucial role in individual intentions to do good or bad things and have an 
impact on moral decisions (Kroll \& Egan, 2004). Moreover, recent findings indicate the transgenerational transmission of mental trauma in Holodomor survivors and their descendants results in emotional distress, in particular feelings of ethnic-related shame and guilt, which are closely related to moral injury (Bezo, 2011; Zasiekina, 2020). However, data about moral injury associated with moral emotions in Holodomor survivors are limited, since there is a strong evidence of their avoidance to share traumatic experience within families (Gorbunova \& Klymchuk, 2020). There is little published data on emotional experience of Holodomor survivors, hence their narratives represent more cognitive and factual information about traumatic events and mostly conceal the Holodomor-related emotional experience. In addition, no research has been found that examined consequences of moral injury in Holodomor survivors.

The study offers some important insights into moral injury in Holodomor victims applying psycholinguistic analysis of their narratives. Hence the morality as a static system of beliefs exists at two levels, notably at social-cultural and individual, the current paper will inform future research of moral injury during genocide from a more culturally appropriate perspective. It will also enable structured prevention and treatment methods to be developed and enhance awareness within the community exposed to the genocide in general, and in the Ukrainian community exposed to the Holodomor in particular.

The purpose of the current research is to define and operationalize moral injury based on moral standards, moral judgements, moral reasoning, moral emotions, moral behaviour, and moral consequences; to explore verbal emotional disclosure of moral injury in the Holodomor survivors' narratives.

\section{Moral injury, mental trauma and PTSD}

Previous research has established that moral injury is frequently compared with mental trauma and PTSD (Coady et al., 2020). In contrast to mental trauma and PTSD, there is much less information about moral injury in genocide context. The experience of moral injury has been demonstrated to lead to a range of psychological distress symptoms (Frankfurt \& Frazier, 2016) which, in addition to traditional PTSD symptom profiles, include higher levels of guilt, anger, shame, depression and social isolation (Griffin et al., 2019). Litz and colleagues (2009) described additional effects of moral injury as demoralization 
(i.e. despair, worthlessness, and meaninglessness) which is closely aligned with the feelings in genocide survivors.

To date, several studies have investigated the impact of potentially morally injurious events on emotions in the context of hostility, notably killing or wounding others, engaging in retribution or disproportionate violence, or failing to save the life of a comrade, child or civilian (Braitman et al., 2018). Evidence of the most recent research of moral injury in Israel consistently suggests that moral injury is associated with suicidality, depression, post-traumatic stress disorder (PTSD) and risk taking behaviors (Baum et al., 2013). Since the Holodomor is associated with a continuous assault on the Ukrainian people, and a case of mass killing by starvation, aligned with violation of core moral standards and beliefs, it could be considered as a case of mass and individual moral injury.

\section{Moral injury and morality}

A large and growing body of literature has investigated moral injury in the context of morality. Litz et al. (2009) define morality as a static belief system, which is represented by cognitive schemas about goodness and perfection. Developing these ideas, Molendijk, Kramer, and Verweij (2018: 40) define morality "as the personal and shared familial, cultural, societal, and legal rules for social behavior, either tacit or explicit» and as "fundamental assumptions about how things should work and how one should behave in the world». Therefore, morality is associated with core beliefs about the self, others and the world. The traumatic event has a negative effect on individual core beliefs and results in cognitive distortions, rejecting that the world is meaningful, others are reliable and the self is worthy. Thus, moral injury is viewed as an act of transgression, since it violates individual perceptions about right and wrong. If the individual cannot accommodate new cognitions within a static system of beliefs, they experience negative moral emotions, in particular guilt and shame. Therefore, moral injury is aligned with all components of morality and is represented by moral standards and moral judgements developing in moral reasoning, moral behaviour, moral emotions and moral consequences (see Figure 1).

Exploring moral injury in accordance with model of morality is in line with the content of moral injury events scale (Bryan et al., 2016) (see Table 1). 


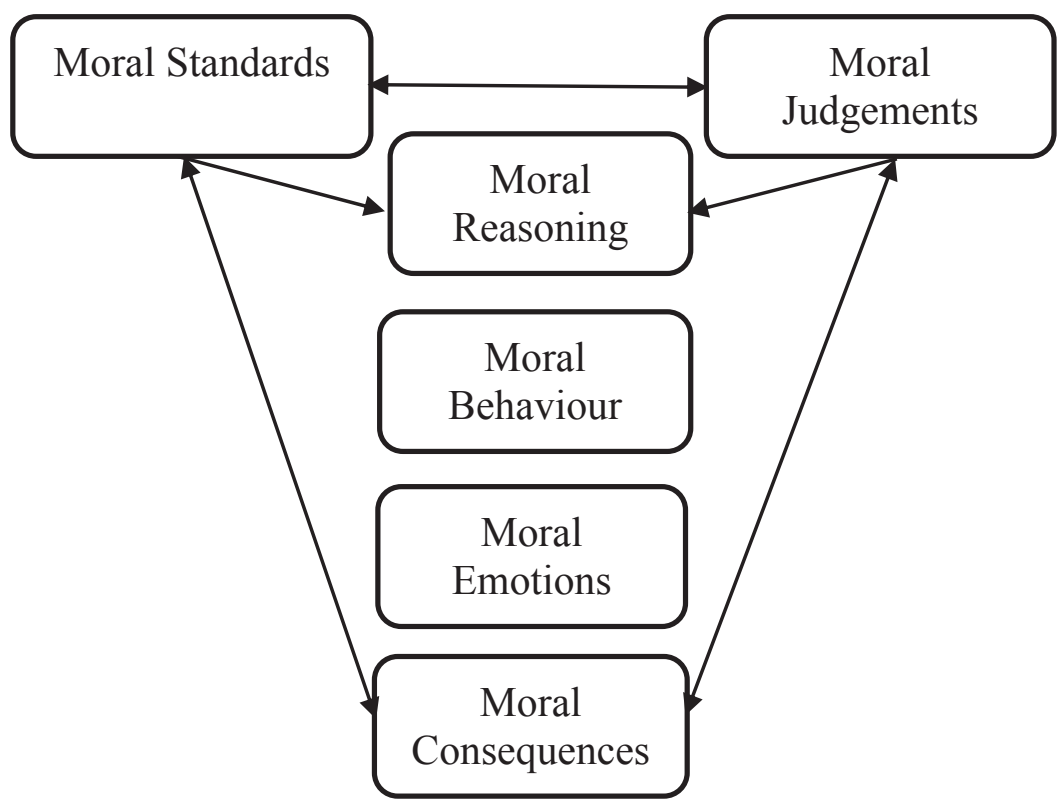

Figure 1. Moral injury aligned with components of morality

Table 1. Structural Analysis of Moral Injury and Content of Moral Injury Events Scale

\begin{tabular}{ll}
\hline Components of moral injury & Content of moral injury event scale \\
\hline Moral standards & (1) I saw things which were morally wrong \\
Moral judgements & (1) I am troubled by having witnessed others' immoral acts \\
Moral behaviour & (1) I acted in ways that violated my own moral code or \\
values & (2) I violated my own morals by failing to do something I \\
Moral reasoning & (3) I have done a moral choice \\
Moral emotions & (1) I am troubled by having acted in ways that violated my \\
own morals or values
\end{tabular}




\section{Methods and Techniques of the Research}

\section{Participants}

42 survivors of the Holodomor of 1932-1933 in Ukraine were recruited for story-telling related to their Holodomor experience. The inclusion criterion for participants was their personal history of being Holodomor survivors. Holodomor survivor is defined as a person who was exposed to the genocide and unprecedented starvation in 19321933. The narratives were recorded and transcribed in 2003-2005, average age of participants is $84.5, \mathrm{SD}=4.8,29$ females and 13 males (see Table 2). The participants represented different Oblasts in Ukraine and were recruited with the formal letters to take part in the study. After consent forms were obtained, the participants were asked to talk freely about the events with the major focus on their thoughts and feelings. After that the traumatic narratives were transcribed and analyzed.

Table 2. Descriptive information for the participants in the current research $(n=42)$ sample

\begin{tabular}{lcc}
\hline & \multicolumn{2}{c}{ Survivors } \\
\cline { 2 - 3 } & Frequency & Percentage \\
\hline Gender & $29 / 13$ & $69.0 / 31.0$ \\
Female/male & & \\
Marital status & 26 & 61.9 \\
Single & 9 & 21.4 \\
Married & 7 & 16.7 \\
Divorced & & 100.0 \\
Ethnicity & 25 & \\
White & & 9.6 \\
Occupational status & 3 & 90.4 \\
Full-time worked & & \\
Part-time worked & 38 & Min-Max \\
Student & & $76-87$ \\
Retired & & \\
Unemployed & Mean (SD) & \\
Age & $84.5(4.8)$ & \\
\end{tabular}

\section{Procedure}

It is now well established from a variety of studies that verbal disclosure of traumatic experience resulted in an enhancing mental 
health and well-being after trauma (Zasiekina, Kennison, Zasiekin \& Khvorost, 2019). In addition, there is a strong association between language and the outcome of PTSD treatment (Pennebaker, 1993). Our previous research has established psycholinguistic approach to reorganization traumatic memory and PTSD treatment, which could be extrapolated for exploring moral injury in the context of the Holodomor (Zasiekina, 2019).

Main concepts and themes aligned with moral standards developing in moral reasoning and moral judgements, moral behaviour, moral emotions, and psychological consequences were captured using guidelines from Rubin and Rubin (2011) and illustrated in Table 3. The study applies software tool NVivo.12 to examine charts, memos, and notes, which were discussed between three experts and developed in the defined themes. Moral standards represent the interiorized moral knowledge about right and wrong things. For instance, it was genocide for Ukrainians; people were weak and begging food express a remarkable deviation from the moral order and moral principles. Moral judgments include moral thoughts and decisions about moral behaviour in others, e.g.: the local government took all edible provision, police [militia] pursued and killed people, who were migrating to cities. Moral reasoning relates to solution of moral problems derived from moral standards and judgements and implies moral choice. For instance, when starving children were dying from starvation and labeled by the Soviet government as 'children of enemies', it is a moral choice to help them to survive. Moral behaviour is represented by specific behavioral acts, which derive from moral reasoning and moral choice, therefore, when individuals see starving people, a natural behavioral response was to give them food, e.g. to help starving people, to adopt the orphans, whose parents died or were arrested; to hide and save food. Moral emotions are represented by individual feelings and attitudes related to accepting or rejecting moral standards, e.g. I felt despair observing dead people opposite my house. Moral consequences are linked to psychological consequences of moral injury, e.g. sufferings, nightmares, obsessive memories.

The study examines the frequency mean for all components and their distribution in the narratives (Figure 2). The study applies LIWC2015 to capture psychological meaningful categories (Nalabandian, Taraban, Pittman \& Maliepaard, 2020). LIWC as a software tool refers to the conceptual framework proposed by Tausczik and Pennabaker (2010) 
to select word meanings linked to the attentional focus, emotionality, social relationships, thinking styles, and individual differences. The current study applies the Ukrainian version of LIWC2015 to capture psychological meaningful categories related to moral emotions and moral reasoning, notably anxiety, anger, sadness, and insights (deep comprehension). The research uses the cross-sectional design utilizing the independent variables of anxiety, anger, insights and dependent variable of moral emotions represented in narratives for multiple linear regression analysis and correlations (2-tailed Pearson r) SPSS. 26 between components of morality, anxiety, sadness and insights.

Table 3. Main themes and concepts of moral injury in Holodomor survivors' narratives*

\begin{tabular}{|c|c|}
\hline $\begin{array}{l}\text { Moral } \\
\text { Standards }\end{array}$ & $\begin{array}{l}\text { I saw many people died; the life of people was terrible; many people died; } \\
\text { swelling girl from starvation; it was a genocide; there was nothing to eat; } \\
\text { mother baked a hedgehog and cat; children of soviet government had much } \\
\text { food to eat and had special lunch in a spacy canteen while we have nothing } \\
\text { to eat at all; I saw many dead people lying outside near our house; village } \\
\text { officials confiscated grain from people; all adult family members have died } \\
\text { and we, children, left alone; police [militia] confiscated everything and beat } \\
\text { my father cruelly; starving children lived at the railway stations; people died } \\
\text { from starvation; there was nothing to eat; people ate cats and dogs; people } \\
\text { died on their ways between villages and cities; my all relatives were deported } \\
\text { to Siberia; children were starving; they called us kurkuls and confiscated } \\
\text { everything; people died from starvation in the villages; all father's family died } \\
\text { from starvation; they confiscated all food; they confiscated everything even } \\
\text { clothes; people had nothing to eat. }\end{array}$ \\
\hline $\begin{array}{l}\text { Moral } \\
\text { Judgements }\end{array}$ & $\begin{array}{l}\text { Head of village council wrote a fake cause for people's death; they did not let } \\
\text { victims go; they chased my parents; they did not take care of starving people; } \\
\text { they punished me for helping a starving girl; they kept grain away from } \\
\text { people; officers were rude; they killed people when they were came nearer to } \\
\text { grain; people were swelling from starvation; they prohibited to herd cattle and } \\
\text { required } 180 \text { liters of milk; they searched for grain and took it away; called } \\
\text { peasants the exploiters and arrested them; arrested and killed my grandfather; } \\
\text { they confiscated all cattle, food and grain; my mother died from starvation; } \\
\text { there were starving, helpless and despaired children everywhere; internal } \\
\text { military troops guarded the entrance to cities and villages; my aunt ate a lot } \\
\text { of green wheat ears and died; people were begging; they arrested people to } \\
\text { confiscate everything from them; peasants were called kulaks or kurkuls and } \\
\text { were massively killed by starvation; they arrested my father, confiscated the } \\
\text { house and left us outdoors in the severe frosts; my father was deported to the } \\
\text { camp; we were eating any substitutes for food; it was a planned genocide; } \\
\text { they forced peasants to enter the collective farms; father found the job in the } \\
\text { mine; family moved into the city; grandmother died in the village; mother } \\
\text { wanted to share food with our neighbours; they were searching for food in the } \\
\text { soil; they confiscated clothes and told that sun would warm up; people came } \\
\text { to Belarus to ask food. }\end{array}$ \\
\hline
\end{tabular}

* Translated from Ukrainian by the article's authors 


\begin{tabular}{|c|c|}
\hline $\begin{array}{l}\text { loral } \\
\text { easoning }\end{array}$ & $\begin{array}{l}\text { I decided to give a piece of bread to a girl who was named a so-called } \\
\text { "daughter of enemies; we decided to eat cats and dogs; we decided to help } \\
\text { starving children; peasants were not exploiters they gave an opportunity to earn } \\
\text { money for peasants in the village; we were weak and decided to sleep all time } \\
\text { instead going to school; we were dying from starvation and my father decided } \\
\text { to pick wheat ears at night; we decided to throw corpses from the carriages } \\
\text { on the rails; we defended our father; we decided to keep our provision in the } \\
\text { forest; family decided to leave grandmother and moved into city; we hid food } \\
\text { from them in the yard. }\end{array}$ \\
\hline $\begin{array}{l}\text { Moral } \\
\text { Behaviour }\end{array}$ & $\begin{array}{l}\text { We scared NKVD a lot; we decided to rescue; I gave a piece of bread to a } \\
\text { swollen girl; we prayed Lord; mother often cried and helped starving people; } \\
\text { we thanked arrested farmers for the opportunity to earn money in the past; we } \\
\text { lay on the road and slept; I left alone and walked in the cemetery and cried; } \\
\text { we migrated from the villages to cities; people stole wheat ears and ate horses; } \\
\text { we adopted an orphan to help her to survivor; we sent the parcels to the } \\
\text { arrested and deported people; we searched for wasted food; people suppressed } \\
\text { their love for children and significant others; cried and suffered; we ate the } \\
\text { grass not to die from starving; children always slept at the classes; we have } \\
\text { hidden our food; we moved to the city; we brought food to neighbours, but } \\
\text { they were already dead; we killed cattle, salted it and hid from the police; we } \\
\text { lied close to each other not to be frozen; we gave starving people potatoes. }\end{array}$ \\
\hline $\begin{array}{l}\text { Moral } \\
\text { Emotions }\end{array}$ & $\begin{array}{l}\text { A great embarrassment: why do healthy people die from embarrassment; } \\
\text { people became cruel; I was hopeless and saw disgust in the eyes of my brother } \\
\text { while eating our dog; when I left alone I felt a despair; we were unhappy } \\
\text { children; I feel sadness remembering all that; we were scared; suppressed } \\
\text { peasants experienced increased anger and anxiety; I remember grief and lost; } \\
\text { I felt contempt for the people who killed my father's family. }\end{array}$ \\
\hline $\begin{array}{l}\text { Moral } \\
\text { Consequences }\end{array}$ & $\begin{array}{l}\text { I still feel fear and permanent anxiety; there are still horrible mental } \\
\text { consequences for people; I have traumatic intrusions in my mind and heart by } \\
\text { present time; I felt loneness, all family has died; I have nightmares with dead } \\
\text { bodies; I will never forget many dead people and suffer traumatic memories } \\
\text { to the end of my life; there was no student in the class anymore; intrusive }\end{array}$ \\
\hline
\end{tabular}

Table 3 illustrates that there were great challenges to morality, especially for moral behaviour, increasing a need for self-preservations and preservations of significant others. The things represented in moral standards of the society and moral judgements of representatives of the Soviet government are qualified as completely wrong, therefore, and moral reasoning and moral behaviour contradicts the traditional patterns. People were becoming despaired with hunger, looking for any eatable thing and any place, which seemed more safe. It is in line with an idea of moral freedom expressing individual moral choices even in extreme situations, hence no one can tell another what is right or wrong (Hare, 1956).

It is apparent from this table that very few moral emotions are aligned with embarrassment, disgust, contempt and decreased empathy, 
moreover the emotions of shame and guilt were not discovered. This finding is contrary to previous studies which have suggested that shame and guilt, notably vicarious collective shame are the primary moral emotions (Bezo \& Maggi, 2015). However, the findings of other research report other-focused moral emotions, righteous anger, contempt, the lack of empathy, and disgust (Tangney et al., 2007). These results corroborate the findings of a great deal of our findings that righteous anger increases in the specific anger-elicited situations as a response to violation of moral standards. Thus, the primary moral emotions in the narratives of Holodomor survivors is anger, contempt, decreased empathy, and disgust. This study supports evidence from previous observations that contempt is associated with violations in the social hierarchy (Rozin, 1999). In the context of the Holodomor there is a violation of social order, which demonstrates that the Soviet government intended to kill the Ukrainian peasants as ethnic and social group in the famine. Disgust as a moral emotion relates to violation of ethic divinity, with assaults on human dignity in the Ukrainian peasants in the Holodomor. The peasants often ate substitutes for food, which were disgustful, poisoned and could kill them. There is an ambivalent disclosure of empathy in Holodomor survivors, one the one hand, a strong desire to help, and, on the other hand, a need to suppress an ability to share emotional experience with significant others.

Figure 1 illustrates the distribution of the categories of moral standards, moral judgements, moral reasoning, moral behaviour, moral emotions, and moral consequences in the narratives.

What stands out in Figure 2 is that there is the highest mean of moral judgements in the narratives. Evidence consistently suggests that death by starvation is the most painful (Naimark, 2015), therefore Holodomor survivors express all their negative and blaming judgements towards people who made them suffer. What is striking about the distribution in this figure is a low frequency of moral emotions and moral consequences. It is in line with other findings proving that people feel difficulties in verbal emotional disclosure of the traumatic memory and narrate a factual information instead of emotional experience (Pennebaker, 1993; Zasiekina et al., 2019).

Closer inspection of Table 4 shows a significant positive correlation found between moral standards and other components of morality, in particular moral judgements, moral reasoning, moral 
consequences, anxiety, sadness and insight. It corroborated with our assumption that moral standards are a starting point in morality injury, and other components are closely associated with them. There was a significant positive correlation between moral emotions and anger, and insights. A possible explanation for this might be that moral emotions in Holodomor survivors are represented by anger, which is consistent with the previous findings (Tangney et al., 2007). In addition, an association between moral emotions and insights might explain the absence of categories of shame and guilt, since the situation of starvation determine the Holodomor-related moral choices and behavioral patterns, aligned with a need of self-preservation.

\section{Frequency Mean}

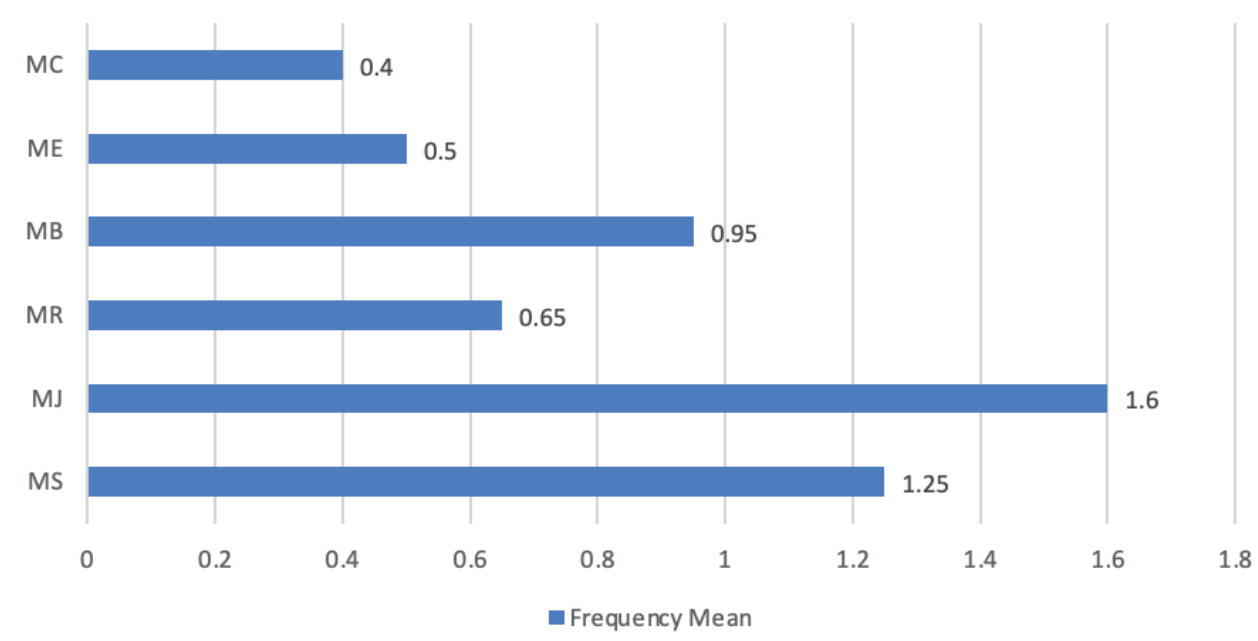

Figure 2. Mean frequency of MS (Moral Standards), MJ (Moral Judgements), MR (Moral Reasoning), MB (Moral Behaviour), ME (Moral Emotions), MC (Moral Consequences)

Multiple linear regression analysis has been used to predict the value of continuous variable moral emotions based on other independent continuous variables, namely anxiety, insights and anger. The assumptions of linear relationship, homoscedasticity, independence of residuals (Durbin Watson $\mathrm{d}=1.68$ ), multicolleniarity (average Tolerance $=0.7>0.2$, and average $\mathrm{VIF}=1.54$, thus $1<\mathrm{VIF}>10$ ) were met. Finally, assumptions regarding normal distribution of data are also met. 
Verbal Emotional Disclosure of Moral Injury in Holodomor...

Table 4. Correlations (2-tailed Pearson r) between components of morality, anxiety, sadness and insights $(\mathrm{n}=42)$

\begin{tabular}{lcccccccccc}
\hline Variables & MS & MJ & MR & MB & ME & MC & Anx & Ang & S & Ins \\
\hline MS & - & $.376^{*}$ & $0.295^{*}$ & .092 & $-.377^{*}$ & $.328^{*}$ & $.276^{*}$ & .012 & $.289^{*}$ & $.331^{*}$ \\
MJ & $.376^{*}$ & - & .180 & $.287^{*}$ & .234 & .175 & $.430^{*}$ & .260 & .025 & .250 \\
MR & $.295^{*}$ & .180 & - & $.313^{*}$ &.-105 &.-287 & $-.313^{*}$ & -.156 & .086 & .031 \\
MB & $.092^{*}$ & $.287^{*}$ & $.313^{*}$ & - & .229 & -.281 & .053 & .076 & .076 & .084 \\
ME & 241 & .234 & -.105 & .229 & - & .204 & .016 & $.329^{*}$ & -.053 & $.344^{*}$ \\
MC & $.328^{*}$ & .175 & -.257 & $.281^{*}$ & .204 & - & .281 & .016 & .129 &.-103 \\
Anx & $.276^{*}$ & .430 & $-.313^{*}$ & .053 & .229 & $.281^{*}$ & - & -.072 & -.080 & -.117 \\
Ang & .012 & .260 & -.156 & .076 & $.329^{*}$ & .016 & -.072 & - & -.080 & $.688^{* *}$ \\
S & $.289^{*}$ & .025 & .086 & .076 &.-053 & .129 & -.080 & .216 & - & -.040 \\
Ins & $.331^{*}$ & .250 & .031 & .084 & $.344^{*}$ &.-103 & -.117 & $.668^{* *}$ & -.040 & - \\
Mean (SD) & 1.25 & 1.60 & .65 & .95 & .50 & .40 & .01 & .10 & .08 & .60 \\
& $(.06)$ & $(1.31)$ & $. .49)$ & $(.22)$ & $(.51)$ & $(.50)$ & $(.06)$ & $(.03)$ & $(.21)$ & $. .65)$ \\
\hline
\end{tabular}

Note. MS=Moral Standards, MJ=Moral Judgements, MR=Moral Reasoning, MB=Moral Behaviour, $\mathrm{ME}=$ Moral Emotions, $\mathrm{MC}=$ Moral Consequences, Anx=Anxiety, Ang=Anger, $\mathrm{S}=$ Sadness, Ins $=$ Insight, $*=\mathrm{p}<05, * *=\mathrm{p}<.01$

The results of the regression with a forced enter method show that three variables (anxiety, insights, anger) explained $31.8 \%$ of word number in traumatic narrative, $R^{2}=.21, F(3,38)=3.19, p=.035$. The results also show that category of anxiety significantly predicts moral emotions, $b=2.329, t(42)=1.98, p=.026$. However, categories of insights, $b=.200, t(42)=1.29, p=.203$ and anger, $b=.893, t(42)=$ $.893, p=.378$ do not significantly predict moral emotions (see Table 5).

Table 5. Summary of multiple linear regression analysis for variables predicting moral emotions for all subjects $(n=42)$

\begin{tabular}{lccccc}
\hline Variables & $\mathbf{B}$ & SEB & $\boldsymbol{\beta}$ & $\mathbf{t}$ & $\mathbf{p}$ \\
\hline Anxiety & 2.329 & 1.27 & .274 & 1.98 & .026 \\
& $(-.242,4.901)$ & & & & \\
Insights & .200 & & .259 & 1.29 & .203 \\
& $(-.112$, & .154 & & & \\
& $.512)$ & & .177 & .893 & .378 \\
Anger & .885 & & & & \\
\hline
\end{tabular}


Strong evidence of anxiety, insights and anger taken together as predictors of moral emotions was found. However, only anger is a robust significant independent predictor of moral emotions. This result may be explained by the fact that the strong violation of Holodomor survivors' rights ruins moral standards and moral order adopted in the Soviet society. Individual moral choice is related to self-preservation and taking care of significant others even when it deviates from society rules. The intention to survive drove a moral behaviour and diminished feelings of shame and guilt in the context of genocide realm instead increased the feeling of righteous anger, embarrassment, disgust, contempt, and decreased empathy.

\section{Conclusion}

The present study was designed to determine verbal emotional disclosure of moral injury in Holodomor survivors. The study examined moral injury according to the components of morality, particularly moral standards, moral judgements, moral reasoning, moral behaviour, moral emotions, and moral consequences. This study has shown that the highest frequency mean score is aligned with moral judgements which represent all traumatic experience of genocidal starvation and blaming the Soviet government and its local representatives for this tragedy.

Verbal emotional disclosure of traumatic experience relates to expressing righteous anger, contempt, disgust, decreased empathy, and embarrassment, which substitute other moral emotions, notably shame and guilt. The study contributes to our understanding of anxiety, anger, insights (deep comprehension) taken together as robust predictors of moral emotions. Finally, we captured that there are difficulties in verbal emotional disclosure of experience and moral consequences of the Holodomor, since the subjects predominantly focus on moral judgements and moral standards. The main moral consequences are represented by great sufferings, intrusive traumatic memories and permanent anxiety. This approach will prove useful in expanding our understanding of how moral emotions relate to moral behavior. In the context of genocide, moral behavior aimed at self-preservation may deviate from the traditional adequate patterns without evoking moral emotions of shame and guilt. 
The scope of this study was limited in terms of narrative analysis and absence of opportunity to specify different components of morality in direct interviews with Holodomor survivors. In spite of its limitations, the study is the first attempt to examine moral injury in Holodomor survivors and certainly adds to our understanding of moral standards, moral judgements, moral reasoning, moral behaviour, moral emotions, and moral consequences in their lives. A natural progression of this work is to analyse transgenerational transgression of moral injury in Holodomor offspring.

\section{Acknowledgments}

The paper is supported by the Holodomor Research and Education Consortium (HREC) of the Canadian Institute of Ukrainian Studies (CIUS), University of Alberta, as a part of the project «Moral Injury: A Comparative Study with Offspring of Holodomor and Holocaust Survivors».

\section{References}

Baum, N.L., Brom, D., Pat-Horenczyk, R., Rahabi, S., Wardi, J., \& Weltman, A. (2013). Transitioning from the battlefield to home: An innovative program for israeli soldiers. Journal of Aggression, Maltreatment and Trauma, 22(6), 644659. https://doi.org/10.1080/10926771.2013.805174

Bezo, B.J.L. (2011). The impact of intergenerational transmission of trauma from the Holodomor Genocide of 1932-1933 in Ukraine. Doctoral dissertation. Carleton University.

Bezo, B., \& Maggi, S. (2015). Living in «survival mode»: Intergenerational transmission of trauma from the Holodomor genocide of 1932-1933 in Ukraine. Social Science \& Medicine, 134, 87-94. https://doi.org/10.1016/j. socscimed.2015.04.009

Braitman, A.L., Battles, A.R., Kelley, M.L., Hamrick, H.C., Cramer, R.J., Ehlke, S., \& Bravo, A.J. (2018). Psychometric properties of a modified moral injury questionnaire in a military population. Traumatology, 24(4), 301-312. https://doi. org/10.1037/trm0000158

Bryan, C.J., Bryan, A.O., Anestis, M.D., Anestis, J.C., Green, B.A., Etienne, N., ... \& Ray-Sannerud, B. (2016). Measuring moral injury: Psychometric properties of the moral injury events scale in two military samples. Assessment, 23(5), 557-570. https://doi.org/10.1177/1073191115590855

Chemtob, C.M., Novaco, R.W., Hamada, R.S., \& Gross, D.M. (1997). Cognitivebehavioral treatment for severe anger in posttraumatic stress disorder. Journal of Consulting and Clinical Psychology, 65(1), 184-189. https://doi.org/10.1037/0022006X.65.1.184

Coady, A., Carney, J.R., Frankfurt, S., \& Litz, B.T. (2020). The Emergence and Development of the Concept of Moral Injury. Moral Injury: A Guidebook for Understanding and Engagement, 21. 
Cryder, C.E., Springer, S., \& Morewedge, C.K. (2012). Guilty feelings, targeted actions. Personality and Social Psychology Bulletin, 38(5), 607-618. https:// psycnet.apa.org/doi/10.1177/0146167211435796

Ellemers, N., van der Toorn, J., Paunov, Y., \& van Leeuwen, T. (2019). The psychology of morality: A review and analysis of empirical studies published from 1940 through 2017. Personality and Social Psychology Review, 23(4), 332366. https://doi.org/10.1177/1088868318811759

Gorbunova, V., \& Klymchuk, V. (2020). The psychological consequences of the Holodomor in Ukraine. East/West: Journal of Ukrainian Studies, 7(2), 33-68. https://doi.org/10.21226/ewjus609

Griffin, B.J., Purcell, N., Burkman, K., Litz, B.T., Bryan, C.J., Schmitz, M., ... Maguen, S. (2019). Moral Injury: An Integrative Review. Journal of Traumatic Stress, 32(3), 350-362. https://doi.org/10.1002/jts.22362

Hare, R.M., \& Hare, R.M. (1991). The language of morals (No. 77). Oxford Paperbacks.

Kroll, J., \& Egan, E. (2004). Psychiatry, Moral Worry, and the Moral Emotions. Journal of Psychiatric Practice, 10(6), 352-360. https://doi.org/10.1097/00131746200411000-00003

Litz, B.T., Stein, N., Delaney, E., Lebowitz, L., Nash, W.P., Silva, C., \& Maguen, S. (2009). Moral injury and moral repair in war veterans: A preliminary model and intervention strategy. Clinical Psychology Review, 29(8), 695-706. https://doi. org/10.1016/j.cpr.2009.07.003

Molendijk, T., Kramer, E.H., \& Verweij, D. (2018). Moral aspects of «moral injury»: Analyzing conceptualizations on the role of morality in military trauma. Journal of Military Ethics, 17(1), 36-53. https://doi.org/10.1080/15027570.2018.1483173

Naimark, N.M. (2015). How the Holodomor Can Be Integrated into our Understanding of Genocide. East/West: Journal of Ukrainian Studies, 2(1), 117-132. https://doi. org/10.21226/T2PP4Z

Nalabandian, T., Taraban, R., Pittman, J.C., \& Maliepaard, S. (2020). Assessing college writing: Do students connect with the text? East European Journal of Psycholinguistics, 7(1), 128-139. https://doi.org/10.29038/eejpl.2020.7.1.nal

Pennebaker, J.W. (1993). Putting stress into words: Health, Linguistic and therapeutic implications. Behavioral Research Therapy, 31, 539-548. https://psycnet.apa.org/ doi/10.1016/0005-7967(93)90105-4

Rozin, P. (1999). The process of moralization. Psychological Science, 10(3), 218-221. https://psycnet.apa.org/doi/10.1111/1467-9280.00139

Rubin, H.J., \& Rubin, I.S. (2011). Qualitative interviewing: The art of hearing data. Thousand Oaks, CA: Sage.

Shen, L. (2018). The evolution of shame and guilt. PloS One, 13(7), e0199448. https:// doi.org/10.1371/journal.pone.0199448

Tangney, J.P., Stuewig, J., \& Mashek, D.J. (2007). Moral emotions and moral behavior. Annual Review of Psychology, 58, 345-372. https://doi.org/10.1146/ annurev.psych.56.091103.070145

Tausczik, Y.R., \& Pennebaker, J.W. (2010). The psychological meaning of words: LIWC and computerized text analysis methods. Journal of Language and Social Psychology, 29(1), 24-54. https://doi.org/10.1177/0261927X09351676

Zasiekin, S., Bezuglova, N., Hapon, A., Matiushenko, V., Podolska, O., \& Zubchuk, D. (2018). Psykholingvalni aspekty perekladu slovnyka LIWC [Psycholinguistic aspects of translating LIWC dictionary]. East European Journal of Psycholinguistics, 5(1), 121-131. https://doi.org/10.5281/zenodo.1436335 
Zasiekina, L. (2020). Trauma, rememory and language in Holodomor survivors' narratives. Psycholinguistics - Psiholingvistika, 27(1), 80-94. https://doi. org/10.31470/2309-1797-2020-27-1-80-94

Zasiekina, L., Kennison, S., Zasiekin, S., \& Khvorost, K. (2019). Psycholinguistic markers of autobiographical and traumatic memory. East European Journal of Psycholinguistics, 6(2), 119-133. Retrieved from: https://eejpl.eenu.edu.ua/index. $\mathrm{php} / \mathrm{eejpl} /$ article/view/25

\begin{abstract}
АНОТАЦІЯ
Метою дослідження є визначити та операціоналізувати поняття моральної травми на основі моральних норм, моральних суджень, моральних умовиводів, моральних емоцій, моральної поведінки і моральних наслідків; дослідити вербально-емоційне виявлення моральної травми в наративах свідків Голодомору.
\end{abstract}

Матеріали та методи. У дослідженні використано травматичні наративи 42 свідків Голодомору 1932-1933 рр. в Україні. За допомогою комп'ютерної програми NVivo.12 було зафіксовано провідні теми, пов'язані зі структурою моралі. У дослідженні застосовується українська версія програми LIWC2015 для визначення психологічно значущих категорій, зокрема тривоги, гніву, смутку й осмислення. Також використовується дизайн крос-поперечного аналізу з незалежними змінними тривоги, гніву, смутку й осмислення і залежною змінною моральних емоцій, представленими в наративах для множинного лінійного регресійного аналізу і кореляцій (коефиієнт Пірсона) SPSS 26 між компонентами моралі, тривоги, смутку й осмислення.

Результати. Визначено високу частотність моральних суджень і низьку частотність моральних емоцій та моральних наслідків у наративах. Найбільше позитивно значущих кореляцій виявлено між моральними нормами й іншими складовими моральності, зокрема, між моральними судженнями, моральними умовиводами, моральними наслідками, тривогою, смутком і осмисленням. Було виявлено значущу позитивну кореляцію між моральними емоціями і гнівом, а також осмсленням. Тривога, осмислення і гнів, взяті разом, $\epsilon$ значущими предикторами моральних емоцій, однак лише гнів - надійний значущий незалежний предиктор моральних емочій.

Висновки. Вербально-емоційне виявлення травматичного досвіду пов'язане з вираженням справедливого гніву, презирства, огиди, зниженої емпатії $i$ збентеження, які замінюють інші моральні емоції, зокрема сором і почуття провини. Це дослідження поглиблює розуміння предикторів моральних емочій, представлених тривогою, гнівом та осмисленням. Установлено труднощі у вербально-емоційному виявленні переживань і моральних наслідків Голодомору, оскільки досліджувані здебільшого зосереджені на моральних судженнях $i$ моральних нормах.

Ключові слова: вербально-емоційне виявлення, моральна травма, моральні норми, моральні судження, моральні умовиводи, моральна поведінка, моральні емоції, моральні наслідки, Голодомор. 


\title{
Засекина Лариса \& Засекин Сергей. Вербально-эмоциональное выявление моральной травмы у свидетелей Голодомора
}

\begin{abstract}
АННОТАЦИЯ
Целью исследования является определение и операционализация моральной травмы на основе моральных норм, моральных суждений, моральных умозаключений, моральных эмоций, морального поведения и моральных последствий; изучение вербально-эмоционального проявления моральной травмы в нарративах свидетелей Голодомора.
\end{abstract}

материалы и методы. В исследовании использованы травматические нарративы 42 свидетелей Голодомора 1932-1933 г2. в Украине. С помощью компьютерной программы NVivo.12 были зафиксированы основные темы, связанные со структурой морали. В исследовании применяется украинская версия программы LIWC2015, для определения психологччески значимых категорий, а именно: тревоги, гнева, печали и осмысления. Кроме того использован кросс-поперечный анализ с независимыми переменными тревоги, гнева, печали и осмысления и зависимой переменной моральных эмоций, представленных в нарративах для множественного линейного регрессионного анализа и корреляций с коэфрфициентом Пирсона (SPSS 26) между компонентами морали, тревоги, печали и осмысления.

Результаты. Отмечена высокая частотность моральных суждений и низкая частотность моральных эмоций и моральных последствий в нарративах. Наибольшее число положительных значимых корреляций обнаружено между моральными нормами и другими составляющими моральности, в частности, между моральными суждениями, моральными умозаключениями, моральными последствиями, тревогой, печалью и осмыслением. Зафиксирована значимая положительная корреляция между моральными эмоциями и гневом, а также осмыслением. Взятые вместе тревога, осмысление и гнев являются значимыми предикторами моральных эмоций, однако только гнев является надежным значимым независимым предиктором моральных эмоций.

Выводы. Вербально-эмоциональное проявление травматического опыта связано с выражением справедливого гнева, презрения, отвращения, сниженной эмпатии и смущения, которые заменяют другие моральные эмоции, в частности стыд и чувство вины. Данное исследование способствует лучшему пониманию тревоги, гнева, осмысления, взятых вместе, как надежных предикторов моральных эмоций. Наконец, было установлено существование трудностей в вербально-эмоциональном проявлении переживаний и моральных последствий Голодомора, поскольку испытуемые в основном сосредоточены на моральных суждениях и моральных нормах.

Ключевые слова: вербально-эмоциональное проявление, моральная травма, моральные нормы, моральные суждения, моральные умозаключения, моральное поведение, моральные эмоции, моральные последствия, Голодомор. 